Short Paper

\title{
Feeding Behaviour of the Japanese Crayfish Cambaroides japonicus (Decapoda, ASTACOIDEA) in a Stream in Hokkaido, Japan
}

\author{
Tadashi Kawai, ${ }^{* 1}$ Tatsuo Hamano, ${ }^{* 2}$ and Shuhei Matsuura*3 \\ ${ }^{*}{ }_{1}$ Hokkaido Central Fisheries Experimental Station, Hamanaka, Yoichi, Hokkaido 046, Japan \\ ${ }^{*}$ National Fisheries University, Yoshimi, Shimonoseki 759-65, Japan \\ ${ }^{*}$ Faculty of Agriculture, Kyushu University, Hakozaki, Higashi, Fukuoka 812, Japan \\ (Received July 1, 1994)
}

Key words: Japanese crayfish, Cambaroides japonicus, food habits, stomach contents, detritus

The Japanese crayfish Cambaroides japonicus lives in streams and lakes of Hokkaido, Aomori, Akita, ${ }^{1)}$ and Iwate Prefectures, in northern Japan. There are few ecological studies of this animal, although it is rare and a protected species. Futhermore, this species is edible ${ }^{2)}$ and reaches up to $70 \mathrm{~mm}$ in body length. ${ }^{3)}$ The study area is a stream in Atsuta, Hokkaido. The stream has tributaries and is about $1 \mathrm{~km}$ long, maximum width of $1 \mathrm{~m}$ and maximum depth of $5 \mathrm{~cm}$. Crayfish were collected monthly from 1990 to 1992 , using a $1 \times 1 \mathrm{~m}$ quadrate $\left(25 \mathrm{~m}^{2}\right.$ in total) by hand. Water temperature was measured from the middle of the stream. Sample were taken between 7:00 to 9:00 a.m., because members of ASTACOIDEA generally feed at night. ${ }^{4}$ Samples were fixed in $15 \%$ formalin immediately after the collection.

In the noble crayfish, Astacus astacus stomach contents for soft shelled animals were empty. ${ }^{5)}$ Therefore, we excluded individuals with soft carapaces, (phases I or II of Kawai $^{6}$ ) from the examination. Carapace lengths were measured from the posterior margin of the eye socket to the posterior margin of the carapace (postorbital carapace length, POCL). Sex was determined by the morphology of the 1 st and 2 nd pleopods and the position of the opening of the gonopores, after Holdich and Reeve. ${ }^{\text {) }}$

Stomach fullness was estimated as the volume of contents/volume of the stomach by eye and recorded to 4 degrees: $0,0.3,0.6$, and 1 . Zero degree designates empty and 1 degree for fully extended stomachs. Data are summarrized for each season i.e., Spring (March-May), Summer (June-August), Autumn (September-November), Winter (December-February).

Thirteen males and 12 females, mean $15.8 \mathrm{~mm}$ (range 9.4-21.3 mm) POCL, collected on 10 August, 1992 were kept in an aquarium at $20^{\circ} \mathrm{C}$ for seven days without food. These individuals with empty stomachs were released into the stream on 16 August and their feeding behavior was observed for $1 \mathrm{~h}$. Then they were recaptured and immediately fixed in $15 \%$ formalin to examine the stomach contents.

The stream is surrounded by trees and a large quantity of fallen leaves covers the bottom of the stream in autumn. Fibrous vegetable material derived from fallen leaves and branches is present on the bottom of the stream all year round, but no water plants were observed. For aquatic animals, Odonata larvae and Gammarus spp. live in the stream.

The mean water temperature of the stream was $6.5^{\circ} \mathrm{C}$ during spring, $17.2^{\circ} \mathrm{C}$ during summer, $12.8^{\circ} \mathrm{C}$ during autumn and $2.6^{\circ} \mathrm{C}$ for winter. The surface of the stream was frozen from December to March. Ninety-two males and 116 females were collected. In spring $38 \%$ of females were ovigerous (Table 1). We observed only crushed fibrous, vegetable material and/or granular materials (Fig. 1-A) in

Table 1. Stomach fullness of the Japanese crayfish collected

\begin{tabular}{|c|c|c|c|c|c|c|c|c|c|}
\hline \multirow{3}{*}{ Sex } & \multirow{3}{*}{ Season $^{* 1}$} & \multirow{3}{*}{$\begin{array}{l}\text { No. of } \\
\text { collected } \\
\text { animals }\end{array}$} & \multicolumn{2}{|c|}{ Carapace length in $\mathrm{mm}$} & \multicolumn{4}{|c|}{ No. of individuals } & \multirow{3}{*}{ Mean fullness } \\
\hline & & & \multirow{2}{*}{ Mean } & \multirow{2}{*}{ Range } & \multicolumn{4}{|c|}{ Stomach fullness $*_{2}$} & \\
\hline & & & & & 0 & 0.3 & 0.6 & 1.0 & \\
\hline \multirow[t]{4}{*}{$\sigma^{*}$} & Spring & 25 & 21.0 & $14.1-30.2$ & 0 & 0 & 0 & 25 & 1.00 \\
\hline & Summer & 36 & 21.2 & $9.2-26.5$ & 0 & 0 & 0 & 36 & 1.00 \\
\hline & Autumn & 22 & 18.1 & $4.6-26.7$ & 0 & 0 & 1 & 21 & 0.98 \\
\hline & Winter & 9 & 26.2 & $20.6-30.3$ & 1 & 8 & 0 & 0 & 0.27 \\
\hline \multirow[t]{5}{*}{ q } & Spring & 26 & 24.5 & $19.5-30.1$ & 0 & 0 & 0 & 26 & 1.00 \\
\hline & & (16) & 24.8 & $20.5-30.1$ & $(0)$ & (0) & $(0)$ & (16) & $(1.00)$ \\
\hline & Summer & 54 & 23.7 & $11.8-31.5$ & 0 & 0 & 1 & 53 & 0.99 \\
\hline & Autumn & 26 & 21.0 & $6.5-32.4$ & 0 & 0 & 4 & 22 & 0.94 \\
\hline & Winter & 10 & 26.3 & $22.5-29.6$ & 1 & 9 & 0 & 0 & 0.27 \\
\hline
\end{tabular}

\footnotetext{
Ovigerous females in parentheses.

*1 Spring: March-May; Summer: June-August; Autumn: September-November; Winter: December-February.

*2 Stomach fullness estimated by eye as volume of contents/volume of the stomach.
} 
the stomachs of specimens, regardless of the sex, ovigerous condition, body size, and season.

The individuals which were starved in an aquarium ate humic leaves and branches in the stream immediately after they were released. Only granular and fibrous vegetable material were observed in the stomachs of recaptured individuals (Fig. 1-B). These materials agreed with that found in the stomach contents (Fig. 1-A) of individuals collected during subsequent regular research described above.

The seasonal changes of stomach fullness are shown in Table 1. Although in spring, summer, and autumn the fullness was almost (i.e. $100 \%$ ), the fullness in winter was only 0.27 . The stomach fullness was similar between sexes and sizes, and between ovigerous and non-ovigerous individuals (Mann-Whituey $U$ test, $P_{\mathrm{s}}>0.05$ ).

As a result, the stomach contents were fibrous vegetable and granular materials. The fibrous material originated from humified, fallen leaves and branches. Kane ${ }^{8)}$ and Fenchel $^{9)}$ considered that the granular materials attached to the humified, fallen leaves are microorganisms. These granular materials observed in stomachs are thought to be microorganisms. Fallen leaves and branches themselves leach nutrients with time as far as they remain in water in such as a stream. However, the nutritional value of fallen leaves is rather fortified in the microorganisms which they subsequently propagate. ${ }^{10)}$ Therefore, crayfishes ingest the microorganisms when they eat these leaves.

Sato ${ }^{11)}$ observed this species preying upon the salamander Hynobius retardatas in a spring. However, we think that the crayfish rarely captures living animals, because they are slow moving. The signal crayfish Pacifastacus leniusculus captures slow-moving organisms such as snails, but it does not hunt fast-moving ones such as Gammarus. ${ }^{12)}$ From these data, the Japanese crayfish in the study stream appears to be a detrital feeder and its main food is humified fallen leaves and branches which have been enriched by the activity of microorganisms. Provenzano ${ }^{13)}$ also reported the main food of ASTACOIDEA to be detritus, thus supporting the present observations.

The stomach fullness of individuals collected was estimated to be more than 0.9 in all seasons, except for the winter, thus we think that in general they always feed on detritus. A similar phenomenon was reported for $A$. astacus from Lake Steinsfjorden; ${ }^{5)}$ i.e., in general stomach fullness is nearly $100 \%$ and decreases during the winter season.

The authors would like to thank Prof. J. F. Fitzpatrick, Jr., Dr. C. Norman, Mr. R. Sakino, and Mr. N. Ikeda.

\section{References}

1) T. Kawai, S. Miyake, and T. Hamano: Researches on Crustacea, 19, 55-61 (1990) (in Japanese).
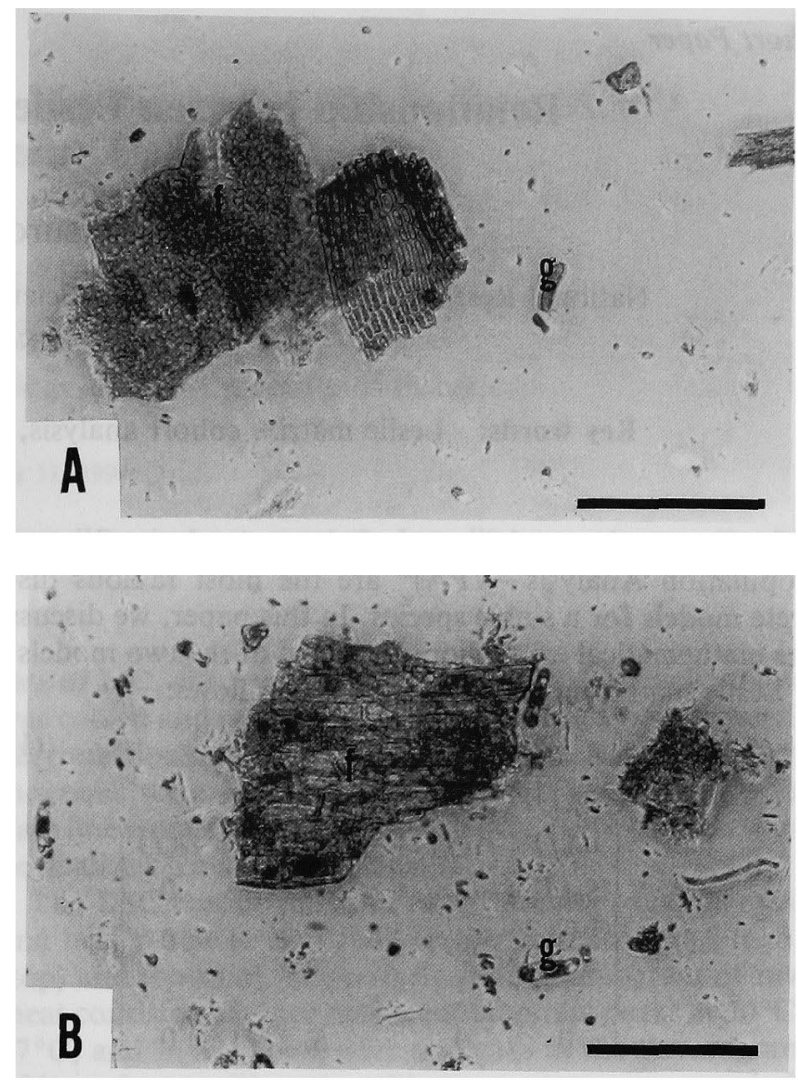

Fig. 1. Stomach contents of Japanese crayfish.

A: stomach contents of a specimen captured. B: stomach contents of a specimen recaptured $1 \mathrm{~h}$ after being released. g, grannle; $\mathrm{f}$, fibrous vegetable material. Scale $=0.05 \mathrm{~mm}$.

2) Kurakami: SAKANA TO TAMAGO, 4, 18 (1953) (in Japanese).

3) S. Miyake: Japanese crustacean decapods and stomatopds in color I, Hoiku-shya, Oosaka, 1982, p. 74 (in Japanese).

4) D. W. Crocker and D. W. Barr: Handbook of the crayfish of Ontario, University of Tronto Press, Canada, 1968, pp. 32-33.

5) D. Q. Hessen and J. Skurdal: in "Freshwater Crayfish" (ed. by P. Brinck), Vol. 6, International Association of Astacology, Lund, 1984, pp. 187-193.

6) T. Kawai: Researches on Crustacea, 21, 89-95 (1992) (in Japanese).

7) D. M. Holdich and I. D. Reeve: in "Freshwater Crayfish" (ed. by D. M. Holdich and S. S. Lowery), Vol. 9, Croom Helm, London, 1988, pp. 11-51.

8) J. E. Kane: Lim. and Oceanogr., 12, 287-294 (1967).

9) T. Fenchel: Lim. and Oceanogr., 15, 14-20 (1970).

10) E. P. Odum: Jpn. J. Ecol., 12, 108-118 (1962).

11) T. Sato: Jpn. J. Herpetol., 13, 131-135 (1990).

12) R. E. Groves: The crayfish, Fishing News Books, Surrey, 1985, pp. 56-61.

13) A. J. Provenzano, Jr.: in "The aquaculture of shrimp, prawn, and crayfish" (Translated from English by A. Imaki et al.), Midorishobou, Tokyo, 1990, pp. 271-274 (in Japanese). 